\title{
Transisi Kepemimpinan Antar Generasi: Studi Kasus di Gereja Kristen Nazarene di Indonesia
}

\author{
Bakhoh Jatmiko \\ Prodi Teologi, Sekolah Tinggi Theologia Nazarene Indonesia, Yogyakarata \\ Email:djatcair@gmail.com
}

\begin{abstract}
The multi-generational workplace is a global phenomenon emerges today. In the various organizations worldwide there will be four to five generations working in the same workfore and at the same time. Nazarene Church in Indonesia is now dealing with this phenomenon. Leadership managment related to inter-generational leadership succession strategy has become an insist issue to elaborate. The objectives of this research are to find data of the diversity of the generation in the denomination and to find strategy to tackle the intergerational leadership succession. This research is conducted by collecting the data from the field and also undergoing literature review to examine the previous theories and reseach foundings related to the topic. The research found that the denomination had clergy from four different generations who are ministering together side by side at the same time. The findings also indicate the urgency of a leadership transition inter generations in this church. Therefore, the author proposes some recomendations as the intergenerational leadership transition strategy, namely: mentoring, strengthened intergenerational leadership, intentional leadership development programs, and intergenerational leadership collaboration.
\end{abstract}

Keywords: Generational Gap; Intergenerational Leadership; Collaborative Leadership; Mentoring; Leadership Succession; Millennial Leadership

\begin{abstract}
Abstrak
Lingkungan kerja multi generasi adalah fenomena global yang muncul dewasa ini. Di berbagai organisasi di seluruh dunia akan terdapat empat hingga lima generasi yang bekerja ditempat dan waktu yang sama. Gereja Kristen Nazarene di Indonesia pada saat ini sedang menghadapi fenomena tersebut. Pengelolaan kepemimpinan yang berkaitan strategi suksesi kepemimpinan lintas generasi menjadi isu mendesak untuk dikaji. Tujuan dari penelitian ini adalah menemukan data tentang keragaman generasi yang ada di gereja dan untuk menemukan strategi untuk mengatasi persoalan suksesi kepemimpinan antar generasi. Penelitian dilakukan dengan menghimpun data dari lapangan dan juga melakukan studi literatur untuk mengkaji teori-teori dan penelitian terdahulu yang berhubungan dengan topik yang dibahas. Penelitian yang dilakukan menemukan bahwa denominasi ini memiliki rohaniawan yang berasal dari empat generasi berbeda yang bersama-sama melayani di waktu yang sama. Temuan juga menunjukkan urgensi transisi kempemimpinan lintas generasi di gereja ini. Oleh karena itu penulis menyampaikan beberapa rekomendasi sebagai strategi transisi kepemimpinan lintas generasi, yaitu: mentoring, penguatan hubungan lintas generasi, program pengembangan kepemimpinan terencana dan kolaborasi kepemimpinan lintas generasi
\end{abstract}


Kata-kata kunci: Jurang Generasi; Kepemimpinan Antar Generasi; Kepemimpinan Kolaborasi; Mentoring; Suksesi Kepemimpinan; Kepemimpinan Milenial

\section{Pendahuluan}

Salah satu isu kepemimpinan yang mengemuka di Gereja Kristen Nazarene (GKN) di Indonesia adalah berkaitan dengan multi-generasi yang ada saat ini. Fenomena ini akan menjadi pengalaman pertama bagai GKN setelah empat dasawarsa ada di Indonesia (McCroskey, 2004, pp. 130-132). Namun demikian, fenomena ini merupakan isu global yang juga dihadapi oleh hampir setiap organisasi di seluruh dunia. Kajian ini pernah dilakukan oleh Bejtkovsky yang mengatakan bahwa tahun 2020 akan menjadi starting point, dimana untuk pertama kalinya dalam sejarah modern, akan terdapat empat atau lima generasi berbeda di dalam dunia kerja yang sama (Bejtkovsky, 2016, pp. 106-107). Menyetujui pemikiran Bejtkovsky; LaCore berpendapat bahwa fenomena ini akan menjadi generasi pekerja terbesar di dalam sejarah peradapan manusia (LaCore, , https://www.emerald.com).

Lebih lanjut, berkaitan dengan implikasi dari fenomena ini, Rajani di dalam penelitiannya menyatakan bahwa hal ini akan menjadi keuntungan sekaligus tantangan yang harus dihadapi oleh organisasi, sebab setiap generasi memiliki perilaku kerja, tujuan, dan aspirasi yang berbeda-beda (Rajani, 2012). Selaras dengan Rajani, Knight menegaskan bahwa berbagai generasi yang ada dalam organisasi yang sama ini memiliki nilai persaingan, pengharapan, dan inventarisasi kecakapan yang berbedabeda (Knight, 2014, http://search.ebscohost.com/). Berbagai penelitian tersebut membawa simpulan bahwa setiap organisasi, termasuk gereja akan memasuki era baru, yaitu era multigenerasi. Organisai-organisasi akan mengalami perubahan dan disrupsi, secara khusus di bidang kepemimpinan. Berbagai organisasi, termasuk gereja perlu memiliki strategi dalam menggumuli fenomena ini. Berikut ini adalah perbandingan periode dan penamaan generasi yang pernah dilakukan oleh para ahli yang dirangkum oleh Oh dan Reeves (Oh, \& Reeves, 2011, http://link.springer.com). 
Tabel 1. Pengelompokan Generasi

\begin{tabular}{|c|c|c|c|c|c|}
\hline \multirow{2}{*}{$\begin{array}{c}\text { Howe \& } \\
\text { Strauss } \\
(2005)\end{array}$} & $\begin{array}{c}\text { Silent } \\
\text { Generation }\end{array}$ & $\begin{array}{c}\text { Boom } \\
\text { Generation } \\
\end{array}$ & $\begin{array}{c}\text { 13th } \\
\text { generation }\end{array}$ & $\begin{array}{c}\text { Millennial } \\
\text { Generation } \\
\end{array}$ & $\begin{array}{c}\text { Generation } \\
\mathrm{Z} \\
\end{array}$ \\
\hline & 1925-1943 & 1943-1960 & 1961-1981 & 1982-2000 & 2004-2025 \\
\hline \multirow{6}{*}{$\begin{array}{l}\text { Lancaster } \\
\text { Stillman } \\
(2010)\end{array}$} & \multirow[t]{5}{*}{ Traditionalists } & \multirow[t]{5}{*}{$\begin{array}{l}\text { Baby } \\
\text { Boomers }\end{array}$} & \multirow[t]{5}{*}{$\begin{array}{l}\text { Generation } \\
\text { Xers }\end{array}$} & $\begin{array}{l}\text { Millennial } \\
\text { Generation }\end{array}$ & \\
\hline & & & & $\begin{array}{l}\text { Echo } \\
\text { Boomer }\end{array}$ & \\
\hline & & & & $\begin{array}{l}\text { Generation } \\
Y\end{array}$ & \\
\hline & & & & $\begin{array}{l}\text { Baby } \\
\text { Buster }\end{array}$ & \\
\hline & & & & $\begin{array}{l}\text { Generation } \\
\text { Next }\end{array}$ & \\
\hline & 1900-1945 & 1946-1964 & $1965-1980$ & 1981-1999 & \\
\hline \multirow[t]{2}{*}{$\begin{array}{l}\text { Martin \& } \\
\text { Tulgan (2002) }\end{array}$} & $\begin{array}{l}\text { Silent } \\
\text { Generation }\end{array}$ & $\begin{array}{l}\text { Baby } \\
\text { Boomers }\end{array}$ & Gen-Xers & Millennials & \\
\hline & 1925-1942 & 1946-1960 & $1965-1977$ & $1978-2000$ & \\
\hline \multirow{4}{*}{$\begin{array}{l}\text { Oblinger } \\
\text { Oblinger } \\
(2005)\end{array}$} & \multirow[t]{3}{*}{ Matures } & \multirow{3}{*}{$\begin{array}{l}\text { Baby } \\
\text { Boomers }\end{array}$} & \multirow[t]{3}{*}{ Gen-Xers } & Gen-Y & \multirow{3}{*}{$\begin{array}{l}\text { Post- } \\
\text { Millenials }\end{array}$} \\
\hline & & & & GenNet & \\
\hline & & & & Millennials & \\
\hline & $<1946$ & 1947-1964 & $1965-1980$ & 1981-1995 & 1995- present \\
\hline \multirow[t]{2}{*}{$\begin{array}{l}\text { Tapscott } \\
(2009)\end{array}$} & & $\begin{array}{l}\text { Baby Boom } \\
\text { Generation }\end{array}$ & $\begin{array}{l}\text { Generation } \\
X\end{array}$ & $\begin{array}{l}\text { Digital } \\
\text { Generation }\end{array}$ & \\
\hline & & 1946-1964 & $1965-1975$ & $1976-2000$ & \\
\hline \multirow{2}{*}{$\begin{array}{l}\text { Zemke } \\
\text { Raines, \& } \\
\text { Filipezak } \\
(2000)\end{array}$} & Veterans & $\begin{array}{l}\text { Baby } \\
\text { Boomers }\end{array}$ & Gen-Xers & Nexters & \\
\hline & $1922-1943$ & 1943-1960 & $1960-1980$ & 1980-1999 & \\
\hline
\end{tabular}

Pemetaan generasi yang dilakukan oleh para peneliti sosial memang tidak memiliki keseragaman. Namun, prinsip dasar dalam penentuan kelompok generasi ini dilakukan berdasarkan periode waktu tertentu dan mengalami serta menjadi saksi peristiwa sejarah, pengalaman sosial, dan peristiwa sejarah tertentu (Pilcher, 481-495, https://www.jstor.org). Berbagai perbedaan yang ditemukan pada umumnya berkaitan dengan penentuan rentang waktu dalam klasterisasi maupun penamaan kelompok generasi tersebut (Bejtkovsky, n.d., pp. 107-108).

Pemetaan generasi ini dilakukan untuk melihat karakteristik masing-masing generasi yang akan memberi manfaat pada pola menejemen, budaya organisasi, kepentingan strategis kepemimpinan, maupun berkaitan dengan isu suksesi kepemimpinan dalam organisasi. Houlihan melihat kepentingan dari pemetaan 
generasi ini dalam kaitannya dengan potensi konflik serta menejemen konflik antar generasi yang sangat mungkin terjadi di dalam konteks organisasi multigenerasi (Houlihan, n.d., pp. 10-12).

Berdasarkan kajian tersebut di atas, pengumpulan data di lapangan berkaitan dengan tahun lahir dan usia para Pelayan di GKN terdapat temuan dimana denominasi ini juga merupakan organisasi multi-generasi. Kategori Pelayan di dalam penelitian ini adalah mereka yang sudah mendapatkan lisensi dari gereja lokal (Pdp), lisensi dari wilayah (Pdm), dan mereka yang sudah ditahbiskan oleh Ketua Umum GKN (Pdt) ("MANUAL 2017-2021 - to make Christlike disciples in the nations," n.d.) pelayan yang didata adalah mereka yang akif melayani dan masih memegang lisensi dari tingkat gereja lokal, wilayah, hingga lisensi pentahbisan dari GKN pusat. Para pelayan yang didata adalah mereka yang aktif melayani sebagai gembala sidang senior, asisten pendeta, pengajar di STT dan staff misi.

Penelitian yang dilakukan di GKN di Indonesia memberikan konfirmasi pada dalil para peneliti sebelumnya tentang fenomena global multi-generasi di dalam organisasi. Pelayan dari Generasi X adalah kelompok terbesar di GKN Indonesia (53\%). Kemudian, 26\% Pelayan termasuk dalam generasi Baby Boomers (lahir di atara tahun 1946-1964). Di lain pihak, Pelayan Millenials di GKN justru bertolak belakang dengan beberapa penelitian sebelumnya, yang hanya $21 \%$ dari total pelayan yang ada (Lihat tabel 2). Penelitian dari Price Waterhouse Coopers menyebutkan bahwa generasi Millenias akan mengisi lebih dari setengah ruangruang kerja secara global di tahun 2020 (Cooper, 2011). Angka ini menjadi petunjuk sekaligus red alert bagi GKN di Indonesia. Denominasi ini kekurangan pelayan dalam usia relatif muda (21-39 tahun).

Urgensi kajian di dalam topik ini juga berkaitan dengan data yang menunjukkan bahwa 57 Pelayan (49\%) telah berusia lebih dari 50 tahun. Mereka adalah generasi mula-mula yang menanam gereja-gereja awal di Indonesia dan sudah melayani lebih dari 30 tahun (McCroskey, 2004, pp. 130-132). Hal ini juga berkaitan dengan usia pensiun para pelayan yang berimplikasi pada diperlukannya pengganti atau penerus pelayanan yang akan ditinggalkann oleh pelayan yang pensiun tersebut. Jika merujuk pada PP nomor 45, pasal 15 tentang usia pensiun, maka pada kurun waktu 10 tahun usia pensiun di Indonesia akan berada pada usia 57-60 tahun ("BPJS Ketenagakerjaan,"https://www.bpjsketena gakerjaan.go.id). Data menunjukkan bahwa $16 \%$ pelayan sudah memasuki usia 
pensiun namun masih terlibat dalam pelayanan baik penuh waktu maupun paruh waktu. Kemudian di dalam kurun waktu 10 tahun, 34\% pelayanan akan masuk dalam usia pensiun. Dengan kata lain, 50\% Pelayan di GKN Indonesia akan memasuki usia pensiun dalam 10 tahun yang akan datang (Lihat tabel 3).

Tabel 2. Kelompok Generasi di GKN Indonesia (Field Sealands Journal for District Assemblies, 2020)

\begin{tabular}{|l|c|c|c|c|c|}
\hline & Jawa-Bali & Papua & Kalimantan & Sulawesi & $\begin{array}{c}\text { Pioner } \\
\text { (Sumatera, West } \\
\text { Papua, NTT, } \\
\text { Maluku }\end{array}$ \\
\hline $\begin{array}{l}\text { Traditionalist } \\
(1922-1945)\end{array}$ & 1 & 2 & & & \\
\hline $\begin{array}{l}\text { Baby } \\
\text { Boomers } \\
(1946-1964)\end{array}$ & 28 & 6 & & 4 & 5 \\
\hline $\begin{array}{l}\text { Generation X } \\
(1965-1980)\end{array}$ & 38 & 8 & 6 & 8 & 3 \\
\hline $\begin{array}{l}\text { Millennials } \\
\text { (Gen Yen } \\
(1981-2000)\end{array}$ & 13 & 5 & & 6 & 8 \\
\hline
\end{tabular}

Grafik 1. Jumlah Pelayan yang Pensiun dalam Sepuluh Tahun

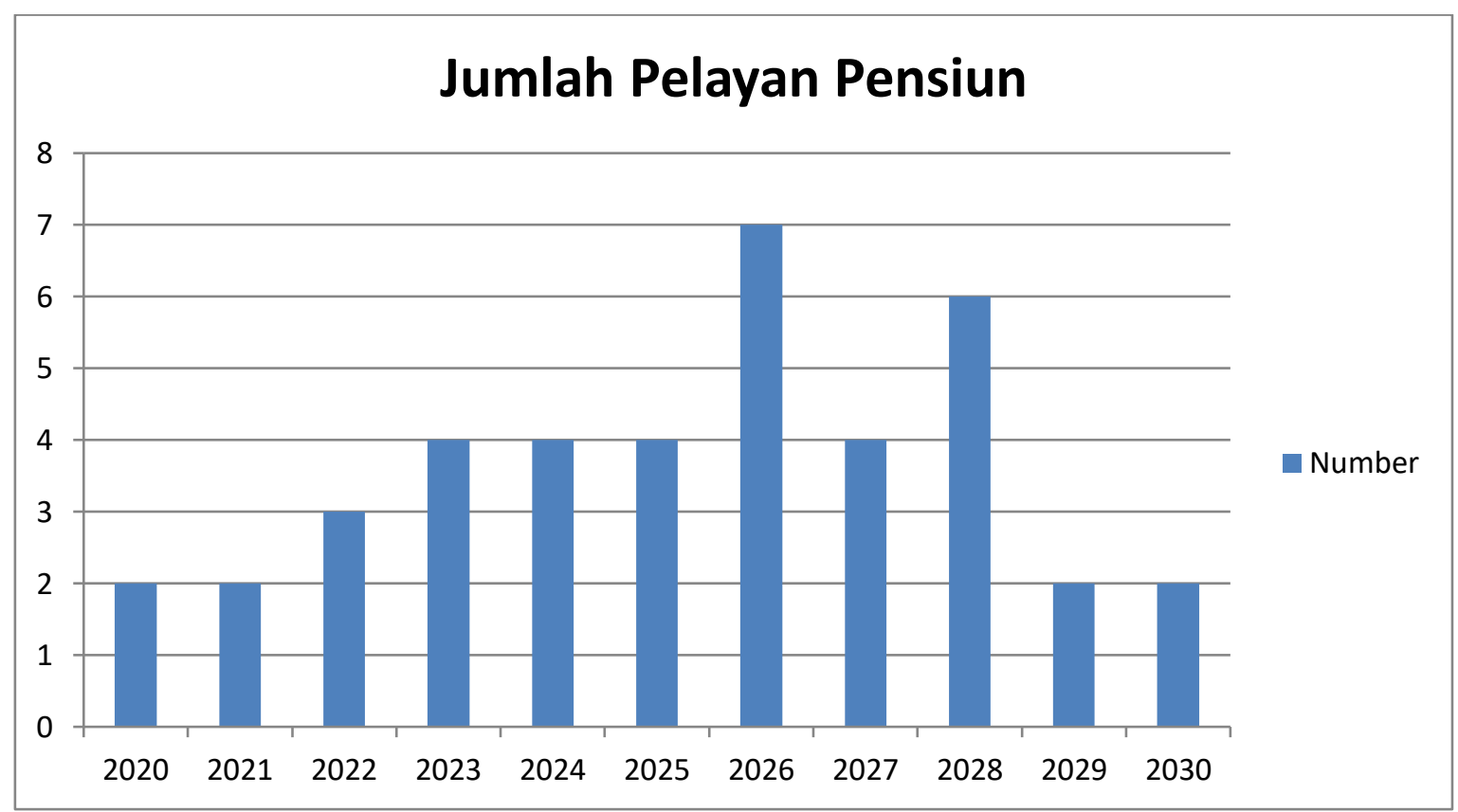


Kajian di dalam artikel ini menunjukkan kebutuhan yang dimiliki oleh GKN Indonesia berkaitan dengan isu kepemimpinan dewasa ini. Strategi dan perencanaan yang matang dan terencana menjadi bahan pemikiran pokok untuk dilakukan oleh pemangku kepentingan dan pimpinan GKN Indonesia. Secara khusus, transisi kepemimpinan akan menjadi "Pekerjaan Rumah" besar yang harus dikerjakan dan mulai dilakukan untuk GKN Indonesia masa kini maupun masa yang akan datang.

\section{Metodologi}

Metode yang digunakan dalam kajian ini adalah deskriptif kualitatif. Data-data berkaitan dengan biodata para pelayan merupakan data sekunder yang dihimpun dari jurnal dan laporan persidangan gereja di setiap wilayah. Teori dan berbagai kajian terkait diambil dari data primer yang berupa buku-buku yang berkaitan langsung dengan objek penelitian, artikel, jurnal dan pemberitaan online, serta beberapa sumber yang menyangkut topik yang diteliti.

\section{Pembahasan dan Hasil}

Riset yang dilakukan telah menyumbangkan temuan bagi GKN baik dalam menyadari potensi maupun juga kebutuhan yang ada. Hal ini mendorong penulis untuk melakukan kajian berkaitan dengan strategi, perencanaan serta model yang cocok dalam menyikapi fenomena yang sedang terjadi di denominasi ini. Bebepara strategi dan program yang diusulkan di dalam artikel ini adalah: mentoring, memperkuat hubungan lintas generasi, program terencana dan model kepemimpinan lintas generasi.

\section{Mentoring}

Data yang menyebutkan bahwa jumlah Pelayan senior di GKN memang membangkitkan kesadaran tentang urgensi suksesi kepemimpinan di denominasi ini. Di lain pihak, para senior di denominasi ini adalah potensi yang besar dengan banyak pengalaman dan pengetahuan di dalam pelayanan. Mereka adalah kelompok yang tepat menjadi mentor bagi pelayan yang lebih muda.

Dalam kaitannya dengan strategi bagi transisi kepemimpinan antar generasi, mentoring adalah "engsel" yang dapat menghubungkan generasi senior dengan generasi yang lebih muda. McDonald menjelaskan bahwa mentoring merupakan proses menghubungkan generasi senior dan generasi yang lebih muda yang kemudian menghasilkan murid yang dewasa yang mampu meneruskan siklus pengembangan kepemimpinan (McDonald, 2004, p. 28). Selaras dengan McDonald, Scott Thomas melihat pentingnya seorang pelayan untuk 
memiliki mentor yang lebih senior dalam perjalanan kedewasaan kepemimpinan mereka sambil juga mementor pelayan lain yang lebih muda (Thomas \& Wood, 2012, pp. 36-37).

Kaderisasi kepemimpinan dengan mentoring bukan hanya merupakan prinsip penting di dalam menejemen kepemimpinan, tetapi juga memiliki dasar-dasar yang kokoh di dalam Alkitab. Berbagai ayat Alkitab mengkaitkan salah satu tugas pemimpin rohani adalah untuk meneruskan transmisi nilai-nilai keimanan melalui pengembangan kepemimpinan (band. Yud. 3, Ul. 6, Mzm. 78, Tit. 2). Paulus juga menjadi teladan dalam model mentoring dalam konteks kepemimpinan rohani. Pemimpin senior menjadi "bapak dalam iman" bagi pemimpin junior (1 Tim. 12). Thomas dan Wood mengatakan bahwa mentoring Alkitabiah (gospel coaching) adalah proyek relasional yang melibatkan tiga aspek dari kehidupan personal seseorang, yaitu: kepribadian sang pemimpin, spiritualitas sang pemimpin, dan misi sang pemimpin ( Thomas \& Wood, 2012, pp. 36-37). Dengan kata lain, pemimpin Kristen harus rela mengambil tanggung jawab untuk mengembangkan kepemimpinan pemimpin lain, salah satunya dengan proses mentoring.

Dalam proses mentoring terjadi transmisi pengalaman maupun pengetahuan dari generasi senior kepada generasi junior. Mentoring adalah proses yang sehat dalam mempersiapkan pemimpin muda pada kapasitas kepemimpinan yang lebih besar. Cohen mendefinisikan mentoring sebagai keterlibatan enam proses yang berlangsung secara simultan yaitu: membangun hubungan dan berbagi informasi; proses fasilitatif dan konfrontatif dalam melakukan refleksi dan pemikiran alternatif; keteladanan; mempertajam visi sehingga pelayan junior mulai memiliki inisiatif untuk pertumbuhan dan pembelajaran mandiri (Cohen, 1995, p. 15). Muir menemukan bahwa hubungan "mentorship" ini mengizinkan pemimpin dari generasi yang lebih muda untuk menemukan identitas mereka (Muir, 2011, p. 28). Selaras dengan pendapat tersebut, Stanley and Clinton mengatakan bahwa inti dari mentoring adalah pemuridan yang dilakukan oleh pihak senior untuk mengembangkan dan mendewasakan pihak junior (Stanley \& Clinton, 1992, p. $38)$.

Mentoring tidak hanya membawa keuntungan bagi pihak yang dimentor (mentees), namun juga membawa manfaat bagi mentor (Ehrich \& Tennent, 2004, pp. 518-540). Mentor memiliki kesempatan untuk membagikan pengalaman hidup sebagai sebuah legacy bagi generasi 
selanjutnya. Secara emosional, pemimpin senior akan terus merasa dilibatkan dan berperan dalam organisasi.

\section{Memperkuat Hubungan}

Tantangan yang dihadapi oleh organisasi lintas generasi adalah munculnya "generational - gap". Perbedaan pengalaman, sudat pandang, orientasi hidup menjadi penyumbang jarak antar generasi yang sering ditemukan di organisasi. Meskipun, “jurang” yang sering dibicarakan tidak sebesar pada kenyataannya, melainkan ada tendensi steriotipe di sana (Rossi, 2007, pp. 10-12). Di lain pihak, jika stigmatisasi tetap dibiarkan berkembang, maka ini akan menjadi generalisasi kelompok usia tertentu.

$$
\text { Ketidakmampuan sebuah }
$$
organisasi dalam mengelola jurang antar generasi ini membuat proses transisi kepemimpinan tidak dapat dijalankan dengan baik. Sebaliknya, sesuai kajian Butler, strategi dan pengelolaan hubungan antar generasi akan mempersempit celah antar generasi dan menolong proses transisi kepemimpinan lintas generasi (Butler, 2010, p. 24). Demikian juga di dalam konteks GKN Indonesia, urgensi penguatan hubungan antar generasi perlu menjadi kajian yang serius.

Kekuatan hubungan antar generasi menjadi kunci penting dalam suksesi kepemimpinan antar pemimpin dari lintas masa. Merujuk pada pola kepemimpinan Paulus, dia menyebut mentees yang ada di bawah bimbingannya sebagai "anak" secara rohani (Band. 2 Korintus). Sebutan ini, menurut Lawless, merupakan "the adoptive element" antara rasul Paulus dan orang-orang yang sedang dia kembangkan dengan penguatan hubungan di antara mereka (Lawless, 2012, pp. 228-229).

Hubungan menjadi semacam pengikat bagi generasi muda untuk bertahan di dalam sebuah organisasi. Thomas O'Daniel, di dalam disertasinya menemukan bahwa banyak pendetapendeta yang masih muda memutuskan untuk tetap tinggal di pelayanannya, ketika memiliki hubungan yang baik dengan seniornya (O’Daniel, 2005, pp. 180). Rendahnya para pelayan yang berusia relatih muda di GKN Indonesia, nampaknya perlu disikapi secara serius, bukan hanya berkaitan dengan transisi kepemimpinan, tetapi juga bagaimana pengelolaan hubungan antar generasi itu dijalankan. Turner mengatakan bahwa hubungan antar generasi di antara pelayan merupakan hal substansial dalam mengembangkan jiwa kepemimpinan pelayan dari generasi yang lebih muda (Turner, 2011, pp. 166). Satu pemikiran dengan hal tersebut, Gregory Belcher mengatakan bahwa setting informal tetapi sarat dengan hubungan yang sehat, 
seorang pelayan yang masih muda akan mendapatkan kesempatan untuk masuk pada level kepemimpinan yang lebih tinggi dan semakin efektif di dalam pelayanannya (Belcher, 2002, pp. 73).

Penguatan hubungan antar generasi juga diperlukan berkaitan dengan psikologi-sosial di pihak generasi yang lebih muda (Millennials, atau Generasi Z). Generasi ini dibesarkan dengan keterlibatan yang besar dari orang tua mereka dan hubungan mengambil porsi yang banyak di dalam pengalaman kehidupan mereka (Myers \& Sadaghiani, 2010, pp. 225-238). Kajian ini menuntut pendekatan yang perbeda terhadap pemimpin dari generasi Millennials dan Z . Mereka lebih suka "to be managed" daripada "to be lead." Oleh karenanya kepemimpinan yang berorientasi pada hubungan sangat diperlukan di dalam menolong generasi yang lebih muda dalam mengoptimalkan potensinya (Balda \& Mora, 2011, pp. 13-24).

\section{Program Pengembangan Kepemimpinan}

\section{Terencana}

Strategi pengembangan kepemimpinan sering kali tidak dapat dipisahkan dari implementasi program yang baik. Keyakinan bahwa pada umumnya pemimpin dibuat, dan bukan dilahirkan memperkuat signifikansi wadah pelatihan dan pengembangan kepemimpinan. Kecakapan, pengetahuan, pengalaman, kematangan kepemimpinan seseorang merupakan pencapaian dalam kepemimpinan yang diraih dari proses yang sengaja dilibatkan. Pakar kepemimpinan modern, John C. Maxwell menyampaikan tujuh alasan dasar mengapa seorang pemimpin perlu dilatih: (1) Kedekatan seorang pemimpin dengan pemimpin lain akan menentukan level sukses pemimpin tersebut.

Perkembangan potensi dalam organisasi berkaitan langsung dengan potensi personal di dalam organisasi tersebut. (3) Pemimpin potensial akan mengambil tanggung jawab yang lebih. (4) Pemimpin potensial akan menarik pemimpin potensial yang lain. (5) Pemimpin yang mementor pemimpin potensial akan melipatgandakan efektifitas kepemimpinannya. (6) Pengembangan kepemimpinan akan memperluas dan memperkuat organisasi di masa yang akan datang. (7) Semakin banyak orang yang dipimpin oleh seorang pemimpin, semakin banyak pula pemimpin yang dibutuhkan (Maxwell, 1995, pp. 3-13).

Dalam konteks GKN di Indonesia, progam pengembangan kepemimpinan yang terencana sangat diperlukan. Strategi ini bukan hanya berkaitan dengan GKN di Indonesia masa kini, tetapi juga masa yang akan datang. Hal ini sesuai dengan pendapat Cahill dan Sedrak yang 
mengatakan bahwa setiap organisasi harus menarik sekaligus mempertahankan generasi yang baru untuk membangun masa depan organisasi dan tetap membuatnya kompetitif serta relevan (Cahill \& Sedrak, 2012, pp. 3-15).

Berkaca pada pengalaman di beberapa waktu terakhir, ketika pengembangan kepemimpinan hanya "diserahkan" kepada Seminari atau institusi pendidikan Teologi Nazarene, terbukti tidak cukup menyediakan apa yang diperlukan gereja (secara jumlah, maupun kualitas pengalaman pelayanan). Para lulusan lembaga pendidikan teologi adalah para pemimpin potensial, memiliki pengetahuan yang memadai tetapi masih memerlukan pengalaman di dalam memimpin. Kolaborasi antara gereja dan institusi pendidikan teologi akan menjadi alat efektif dalam bersoal tentang isu ini. Peran aktif gereja harus dinyatakan dalam menyediakan training, choacing dan mentoring bagi pemimpin-pemimpin potensial yang masih muda.

Kemitraan yang kuat antara gereja dan institusi pendidikan menjadi kunci penting bagi urgensi kepemimpinan di GKN di Indonesia. Dalam penelitian yang dituangkan dalam disertasinya, Hancock memformulasikan empat macam program yang dapat diimplementasikan dalam rangka mengembangkan kepemimpinan bagi generasi muda di gereja (Hancock,
2017, pp. 86-96). Program ini relevan dengan kebutuhan GKN di Indonesia dan sangat mungkin diterapkan untuk menjawab persoalan kepemimpinan yang ada di dalamnya.

$$
\text { Pertama, program magang }
$$
(apprenticeship). Di dalam kesempatan ini, pelayan yang masih muda mendapatkan kesempatan belajar dari pelayan senior yang sudah memimpin selama beberapa waktu. Kerinduan untuk belajar dan kerelaan untuk membimbing sangat diperlukan di dalam proses ini. Hancock memberikan rekomendasi untuk membuat program ini berjalan dengan efektif diperlukan waktu satu hingga empat tahun. Kedua, program kelompok (cohort program). Program ini dilaksanakan secara kolektif. Beberapa pelayanan dalam sebuah tim yang diutus ke sebuah gereja atau "ladang" pelayanan tertentu untuk sama-sama belajar, mendewasakan dan melayani. Dalam proses ini diperlukan pemimpin-pemimpin senior untuk mendampingi, menguatkan, dan melihat perkembangan potensi para trainees. Ketiga, program institusional (institute program). Program ini dilakukan secara intensif dengan berbagai kegiatan yang lebih tertata dan terjadwal seperti penyajian materi dalam kelas, kursus, seminar, belajar kelompok, atau coaching dan mentoring yang lebih formal. Program ini biasanya memerlukan waktu satu 
hingga dua tahun. Keempat program residensi. Program ini dilakukan dengan merekrut fresh graduate dari seminari untuk melayani di bidang pelayanan tertentu sebagai persiapan untuk proses kepemimpinan yang selanjutnya (Misalnya pendeta residensi di sekolah). Di tahap ini, trainees akan belajar sambil mendapatkan mentoring dari para pelayan senior sambil dilakukannya proses persiapan penempatan pada posisi dan tempat yang lebih tetap. Program ini dapat dilakukan dalam kurun waktu satu hingga tiga tahun.

\section{Kolaborasi Kepemimpinan Lintas}

\section{Generasi}

Data yang dihimpun di dalam penelitian ini menunjukkan bahwa GKN di Indonesia merupakan denominasi lintas generasi. Empat generasi berbeda ada di ladang pelayanan yang sama dan melayani bersama-sama. Hal ini menjadi tantangan sekaligus potensi yang harus dikelola dengan baik. Sebagai organisasi multi generasi, kepemimpinan yang merupakan bentuk dari kolaborasi antar generasi adalah opsi yang relevan dalam proses transisi kepemimpinan di gereja.

Kajian ini memberikan alternatif yang berkaitan dengan model kepemimpinan yang juga berhubungan dengan strategi transisi kepemimpinan lintas generasi. Model kepemimpinan ini dapat menjadi alternatif bagi model "tradisional" yang berkaitan dengan transisi kepemimpinan. Misalnya, The Wavering leadership transition model atau kepemimpinan "menunggu;" dimana transisi kepemimpinan hanya terjadi apabila pemimpin senior meninggal, sakit parah, pensiun, atau dipecat karena persoalan tertentu. Di dalam model menunggu, tidak ada persiapan, pelatihan dan pemberdayaan pemimpin-pemimpin muda. Kepemimpinan tergantung pada pemimpin senior yang biasanya merupakan seorang pemimpin yang berkarisma.

Model kepemimpinan kolaboratif ini juga dapat menjadi alternatif bagi transisi kepemimpinan yang berorientasi pada senioritas, atau model kepemimpinan "urut kacang." Model ini berkeyakinan bahwa yang tua, yang senior, yang berpengalaman yang memimpin. Model ini membuat peran kepemimpinan di level tertentu hanya diisi oleh pemimpinpemimpin dari kelompok usia tertentu saja dan kelompok usia di bawahnya tidak diberikan kesempatan mengembangkan potensi kepemimpinannya.

Sementara itu, kolaborasi kepemimpinan lintas generasi adalah kepemimpinan yang berupa tim, jamak, shared-leadership dimana para pemimpin dari berbagai generasi duduk bersama- 
sama untuk memimpin di level kepemimpinan yang sama.

Kepemimpinan kolaboratif ini memberi ruang untuk berbagai potensi dari setiap generasi. Dalam berbagai konteks organiasai, model kepemimpinan ini memberikan ruang bagi berbagai macam generasi (Kaplan, Larkin, \& Hatton-Yeo, 2009). Kreatifitas dan energi dari pemimpin berusia duapuluhan; ketajaman analisa pemimpin di usia pertengahan tiga puluhan hingga empat puluhan; jaringan dan relasi dari pemimpin berusia lima puluhan; serta pengalaman dari pemimpin enampuluhan dapat dikolaborasikan menjadi kekuatan yang besar bagi organisasi. Kolaborasi ini memungkinkan gereja memiliki kesempatan yang lebih besar untuk meraih pencapaian-pencapaian maksimalnya.

Kepemimpinan kolaboratif akan menyeimbangkan ritme organisasi. Albion dan Gutke menjelaskan bahwa kepemimpinan kolaboratif (shared leadership) akan membuat irama organisasi lebih stabil (Albion \& Gutke, 2010). Pemimpin serta gaya kepemimpinan yang dimiliki akan menentukan gerak organisasi. Misalnya, jika semua pemimpin di top level adalah mereka yang berusia tujuh puluhan, maka semua keputusan yang diambil adalah keputusan-keputusan yang aman, tanpa gejolak, cenderung menghindari tantangan dan enggan mengambil resiko. Sebaliknya, jika organisasi dipimpin oleh pemimpin yang semuanya berusia dua puluhan, maka organisasi tersebut akan diwarnai dengan inisiatif, ide, program, proyek yang selalu baru. Hal tersebut akan membuat organisasi mengalami kelelahan dan kehabisan sumber daya. Oleh karena itu, ketika di puncak kepemimpinan terdapat kolaborasi dari berbagai generasi, akan terdapat hikmat, pertimbangan, arahan sebelum sebuah keputusan diambil. Teamwork adalah kunci kesuksesan sebuah organisasi. Hal ini akan memberikan kesempatan bagi sebuah organisasi untuk melipatgandakan dampaknya. Kekuatan banyak orang tentu lebih besar daripada satu orang.

Keuntungan lain dari sharedleadership model adalah akan bergesernya budaya kepemimpinan posisional kepada budaya kepemimpinan fungsional. Aldrin dan Gayatri melihat bahwa pengaruh dan efektifitas seorang pemimpin lebih banyak ditentukan oleh fungsinya dari pada posisi atau jabatannya (Aldrin \& Gayatri, 2014). Berbagai ekses negatif dari kepemimpinan posisional juga dapat direduksi dengan budaya baru ini. Intrik dan politik yang seringkali terjadi di gereja dikarenakan perebutan posisi, karena mereka yang memimpin adalah mereka yang duduk di posisi itu. Sebaliknya, model kepemimpinan kolaboratif ini akan 
memaksimalkan potensi, dan bukan posisi. Mereka yang memiliki kemampuan yang memimpin. Setiap potensi akan diberikan peran. Memberi ruang yang luas bagi rotasi kepemimpinan karena kepemimpinan bukan merupakan hirarki dan posisi.

Kepemimpinan kolaboratif akan menjadi bagian integral dari strategi dan rencana dalam transisi kepemimpinan. Model ini akan mengembangkan potensi pemimpin muda sekaligus mempersiapkan mereka sebagai suksesor jika diperlukan setiap saat (Saccone, 2012, p. 21). Tidak akan ada krisis kepemimpinan jika model ini dijalankan dengan baik. Mengingat peran setiap fungsi kepemimpinan di dalam gereja memiliki peran yang sangat signifikan (Jatmiko, 2020).

Efektifitas dan perkembangan pelayanan sangat tergantung oleh keterlibatan para pemangku kepentingan yang ada di gereja. Hal ini diakomodir oleh sifat kepemimpinan ini yang melibatkan banyak pihak untuk berperan (Albion \& Gutke, 2010, p. 4). Level keterlibatan di dalam gereja akan berbanding lurus dengan produktifitasnya. Semakin banyak generasi yang terlibat, semakin besar sense of belonging di dalam gereja.

Dengan berbagai keuntungan tersebut, model kepemimpinan ini mulai harus dipikirkan oleh GKN di Indonesia.
Kepemimpinan jamak sangat relevan dan sesuai dengan aturan dan tata gereja GKN. Selain berguna bagi transisi kepemimpinan lintas generasi, model kepemimpinan ini juga memberikan harapan akan masa depan gereja.

\section{Kesimpulan}

Penelitian yang dilakukan di GKN di Indonesia memberikan konfirmasi pada dalil para peneliti sebelumnya tentang fenomena global multi-generasi di dalam organisasi. Temuan menunjukkan bahwa GKN di Indonesia memiliki pelayan multigerenasi yang berasal dari empat generasi yang berbeda dan berada di organisasi yang sama dalam waktu yang sama pula. Fenomena kepemimpinan ini merupakan fenomena yang unik sekaligus menantang.

Temuan lain dari penelitian ini adalah adanya kebutuhan yang mendesak yang harus diatasi berkaitan dengan suksesi kepemimpinan antar generasi. Seperti yang disebutkan di dalam pembahasan, $47 \%$ Hamba Tuhan di GKN akan memasuki usia pensiun dalam 10 tahun kedepan. Kenyataan ini mengharuskan gereja memiliki strategi khusus untuk mengelola keragaman generasi yang dalam waktu bersamaan melayani di organisasi yang sama. Data yang dihimpun dari penelitian ini menunjukkan bahwa isu ini sangat penting 
untuk segera ditindaklanjuti. Potensi krisis kepemimpinan, keguncangan organisasi dan kekosongan kepemimpinan akan sangat mungkin terjadi jika gereja tidak mengambil langkah-langkah strategis. Penulis memberikan beberapa rekomendasi dan strategi untuk mengatasi persoalan suksesi antar generasi. Beberapa langkah strategis yang dapat dilakukan oleh GKN dalam situasi ini adalah: mentoring, penguatan hubungan lintas generasi, program pengembangan kepemimpinan terencana dan kolaborasi kepemimpinan lintas generasi. Kajian akhir dari artikel ini masih merupakan proposal bagi denominasi ini yang membutuhkan kajian lebih mendalam, dan tidak kalah pentingnya sebuah action-plan untuk merealisasikannya.

\section{Daftar Pustaka}

Albion, P. R., \& Gutke, H. J. (2010).

Successful succession through shared leadership: Preparing a new generation of educational leaders. Proceedings of the Sydney Symposium: The Future of Teacher Education and School Leader Education, 62-63. Aldrin, A., \& Gayatri, R. (2014). Leadership Not A Title Nor A Position. International Journal of Current Research and Academic Review, 2(8), 356-366. Retrieved from http://www.ijcrar.com/vol-2-
8/Anitha Aldrin and R.Gayatri.pdf Balda, J. B., \& Mora, F. (2011). Adapting leadership theory and practice for the networked, millennial generation. Journal of Leadership Studies, 5(3), $13-24$.

https://doi.org/10.1002/j1s.20229

Bejtkovsky, J. (2016). The Employees of Baby Boomers Generation, Generation X, Generation Y and Generation Z in Selected Czech Corporations as Conceivers of Development and Competitiveness in their Corporation. Journal of Competitiveness, 8(4), 105-123. https://doi.org/10.7441/joc.2016.04.0 7

Belcher, G. (2002). The Relationship of Mentoring to Ministerial Effectiveness among Pastors of the Southern Baptist Convention. The Southern Baptist Theological Seminary.

BPJS Ketenagakerjaan. (n.d.). Retrieved October 2, 2020, from https://www.bpjsketenagakerjaan.go.i d/page/Program-JaminanPensiun.html Butler, P. I. (2010). Succession Planning In Homeland Security - How Can We Ensure The Effective Transfer Of Knowledge To A New Generation Of Employees? (Vol. 298). Naval Postgraduate School. 
Cahill, T. F., \& Sedrak, M. (2012).

Leading a Multigenerational

Workforce: Strategies for Attracting and Retaining Millennials. Frontiers of Health Services Management, 29(1), 3-15.

Cohen, N. (1995). Mentoring and Adult Learners: A Guide for Educators and Trainers. Malabar, KL: Krieger.

Cooper, P. (2011). Millennials at work: Reshaping the workplace. Pricewaterhouse Coopers International Limited (PwCIL), 1-28. Retrieved from https://www.pwc.com/co/es/publicaci ones/assets/millennials-at-work.pdf

Douglas Muir. (2011). Leader Identity Through Mentoring: A Case Study. Northern Illinois Universit.

Ehrich, L. C., Hansford, B., \& Tennent, L. (2004). Formal Mentoring Programs in Education and Other Professions:

A Review of the Literature.

Educational Administration

Quarterly, 40(4), 518-540. https://doi.org/10.1177/0013161X042 67118

Field Sealands Journal for District Assemblies. (2020).

Hancock, A. T. (2017). Pastoral Training Approaches In The Local Church: A Multi-Case Study. Southern Baptist Theological Seminary.

Houlihan, A. (n.d.). The new melting pot:
How to effectively lead different generations in the workplace.

Supervision, 68(9).

Jatmiko, B. (2020). Optimalisasi FungsiFungsi Jabatan Kepemimpinan Gerejawi sebagai Salah Satu Perwujudan Pelayanan yang Holistik. Sanctum Domine: Jurnal Teologi, 8(2), 133-156.

https://doi.org/10.46495/sdjt.v8i2.54

Kaplan, M., Larkin, E., \& Hatton-Yeo, A. (2009). Leadership in

Intergenerational Practice: In Search of the Elusive "P" Factor - Passion. Journal of Leadership Education, 7(3), 69-82.

https://doi.org/10.12806/V7/I3/TF3

Knight, R. (2014). Managing People from 5 Generations. Retrieved September 16, 2020, from Harvard Business Review Digital Articles website: http://search.ebscohost.com/login.asp $\mathrm{x}$ ?direct $=$ true $\& \mathrm{db}=\mathrm{bth} \& \mathrm{AN}=118647$ 749\&site=ehost-live

LaCore, E. (2015). Supporting millennials in the workplace. Strategic HR Review, 14(4), SHR-06-2015-0046. https://doi.org/10.1108/SHR-062015-0046

Lawless, C. (2012). Paul's Missionary Methods. In R. Plummer \& J. M. Terry (Eds.), Paul's Missionary Methods. Downers Grove, IL: InterVarsity Press. 
MANUAL 2017-2021 - to make

Christlike disciples in the nations.

(n.d.). Retrieved September 24, 2020,

from

https://2017.manual.nazarene.org/

Maxwell, J. C. (1995). Developing the

Leaders Around You: Hall' to Help

Others Reach Their Full Potential.

Nashville: Thomas Nelson

Publishers.

McCroskey, R. D. (2004). Planting the

Church of the Nazarene in Indonesia

- A Historical Study of Her First

Thirty Years Evaluated in Light of

Biblical Missiological Chucrh

Growth Principles with Implications

for the Future Growth. Sekolah

Tinggi Teologia Injili Indonesia.

McDonald, L. (2004). So What Is

Mentoring? Journal of Christian

Nursing 21.

Myers, K., \& Sadaghiani, K. (2010).

Millennials in the Workplace: A

Communication Perspective on

Millennials' Organizational

Relationships and Performance.

Journal of Business and Psychology, 25(2), 225-238.

O'Daniel, T. (2005). A Relationship

Analysis Between Mentoring and

Leadership Development within the

United Pentecostal Church

International. The Southern Baptist

Theological Seminary.
Pilcher, J. (1994). Mannheim's Sociology of Generations: An Undervalued Legacy. The British Journal of Sociology, 45(3), 481. https://doi.org/10.2307/591659

Rajani, N. (2012). Engaging Generations at Workplace.

Rossi, J. (2007). What Generational Gap? Academic Search Premier, 61(11), $10-11$.

Saccone, S. (2012). Protege: Developing Your Next Generation of Church Leaders. Downers Grove, Illinois: InterVarsity Press.

Scott Thomas, \& Wood, T. (2012). Gospel Coach: Shepherding Leaders to Glorify God. Grand Rapids, Michigan: Zondervan.

Spector, J. M., Merrill, M. D., Elen, J., \& Bishop, M. J. (Eds.). (2014).

Handbook of Research on

Educational Communications and Technology. https://doi.org/10.1007/978-1-4614$3185-5$

Stanley, P., \& Clinton, R. (1992). Connecting: The Mentoring Relationships You Need to Succeed in Life. Colorado Springs: NavPress.

Turner, R. (2011). Leadership

Development Process of Select House Church Networks in North America: A Multi-Case Study. The Southern Baptist Theological Seminary. 